UDC $78.01+78.03+782$

DOI https://doi.org/10.31723/2524-0447-2020-30-2-2

Tetiana Oleksandrivna Kaznacheieva

ORCID: 0000-0002-8692-2844

PhD in Arts, Assistant Professor,

Assistant Professor at the Department of Common and Specialized Piano

Odessa National A. V. Nezhdanova Academy of Music

itaniamusic@gmail.com

\title{
THE SPECIFICITY EMBODIMENT OF THE HOPAK GENRE IN OPERA AND DOMESTIC DANCE PRACTICE
}

The purpose of the article. The article deals with the specific features of the implementation of the hopak dance genre in such a complex stage form of musical art as an opera and certain signs of its existence in domestic practice. The research and comparison of the implementation of the hopak in the opera, its use as a means of revealing an image in ballet performances and the characteristic features of various domestic variants provides an opportunity to analyze a number of issues directly related to this problem. The methodology. Historical, comparative and analytical methods have been applied to provide an opportunity to reveal the essence of differences in the implementation of the dance genres in stage forms of musical art and their domestic genre analogues. The scientific novelty is to consider the influence of the category of stage effectiveness on the specifics of the dramaturgy of the hopak dance genre. Considering an example of the well-known Ukrainian operas by S. Hulak-Artemovsky and M. Lysenko, a stage variant of a dance, which involves clarity, technical perfection of movements, artistic completeness of the composition, was analyzed. The hopak in domestic performance is characterized by improvisation of the interpretation of time and movements, freedom of sequence of specific dance figures that are born directly during the performance of the dance without prior training. Conclusions. A heroic historical tradition and the natural attraction of the Ukrainian ethnos to martial arts are decisive factors in preserving the popularity of the hopak dance genre. A common feature of different variants of this dance is the common basis of the meter and rhythmic structure of the dance - an anapaest foot of a free character. The stage hopak is a complex, multi-component, artistic and imaginative phenomenon. The hopak, performed in everyday life, is an eternally moving living element of ingenuous creativity, not subject to any systematization and any conditional framework. Characteristically, in any variant of the hopak, signs of the dance competition are clearly revealed. The stylistic nature of the implementation of movements depends directly on

(C) Kaznacheieva T. O., 2020 
such factors as stage effectiveness, and in the common variety the geographic affiliation is also of prime importance.

Key words: hopak, dance genre, stage effectiveness of dance, dance in opera, domestic hopak.

Казначеєва Тетяна Олександрівна, кандидат мистецтвознавства, доцент, доцент кафедри загального та спеціалізованого фортепіано Одеської національної музичної академії імені А. В. Нежданової

Специфіка втілення жанру гопака в опері й у побутовій танщювальній практищі

Мета роботи. У статті розглядаються специфічні особливості втілення танцювального жанру гопака в такій складній сценічній формі музичного мистецтва, як опера, і певні ознаки його існування в побутовій практиці. Дослідження та порівняння реалізації гопака в опері, його використання як засобу розкриття образу в балетних виставах і розгляд характерних рис побутових варіантів танцю, дає можливість проаналізувати низку питань, безпосередньо пов'язаних із зазначеною проблемою. Методологія дослідження. Застосовано історичний, компаративний та аналітичний методи, що дають змогу розкрити сутність відмінностей утілення танцювальних жанрів у сиенічних формах музичного мистецтва та їх побутових жанрових аналогів. Наукова новизна полягає в розгляді впливу категорії сценічності на специфіку драматургії танцювального жсанру гопака. На прикладі відомих українських опер С. Гулака-Артемовського та М. Лисенка проаналізовано сценічний варіант танцю, що передбачає чіткість, технічну досконалість виконання рухів, художню завершеність композиції. Гопак у побутовому виконанні вирізняється імпровізаційністю інтерпретації часу і рухів, свободою послідовності конкретних танцювальних фігур, які народжуються безпосередньо під час виконання танцю без попередньої підготовки. Висновки. Героїчна історична традиція $і$ природна тяга українського етносу до бойових мистецтв є визначальними факторами збереження популярності танцювального жанру гопака. Загальною властивістю різних варіантів цього танцю є спільна основа метроритмічної структури танцю - стопа анапеста, що вільно варіюється. Сценічний гопак складний, багатокомпонентний художньо-образний феномен. Гопак, що виконується в побуті, - жива стихія безпосереднього творчості, що вічно рухається й не підкоряється ніякій систематизації та ніяким умовним рамкам. Характерно, що в будь-якому варіанті гопака виразно проявляються ознаки танцювального змагання. Стилістичний характер виконання рухів безпосередньо залежить від такого фактору, як сценічність, а в побутових різновидах неабияке значення має географічна належність.

Ключові слова: гопак, танцювальний жанр, сценічність танцю, танець в опері, побутовий варіант гопака. 
Казначеева Татьяна Александровна, кандидат искусствоведения, доцент, доцент кафедры общего и специализированного фортепиано Одесской национальной музыкальной академии имени А. В. Неждановой

Специфика воплощения жанра гопака в опере и в бытовой танцевальной практике

Цель работы. В статье рассматриваются специфические особенности воплощения танцевального жанра гопака в такой сложной сценической форме музыкального искусства, как опера, и определенные признаки его существования в бытовой практике. Исследования и сравнения реализации гопака в опере, его использование как средства раскрытия образа в балетных спектаклях и рассмотрение характерных черт бытовых вариантов таниа, дает возможность проанализировать ряд вопросов, непосредственно связанных с указанной проблемой. Методология исследования. Применен исторический, компаративный и аналитический методы, которые дают возможность раскрыть сущность различий воплощения танцевальных жканров в сценических формах музыкального искусства и их бытовых жсанровых аналогов. Научная новизна заключается в рассмотрении влияния категории сиеничности на специфику драматургии танцевального жанра гопака. На примере известных украинских опер С. Гулака-Артемовского и Н. Лысенко проанализирован сценический вариант таниа, предполагающий четкость, техническое совершенство исполнения движений, художественную завершенность композиции. Гопак в бытовом исполнении отличается импровизационностью интерпретации времени и движений, свободой последовательности конкретных танцевальных фигур, которые рождаются непосредственно во время исполнения танца без предварительной подготовки. Выводы. Герочческая историческая традиция и естественная тяга украинского этноса к боевым искусствам являются определяющими факторами сохранения популярности танцевального жанра гопака. Общим свойством различных вариантов этого танца является основа метроритмической структуры танца - свободно варьируемая стопа анапеста. Сценический гопак-сложный, многокомпонентный, художественно-образный феномен. Гопак, исполняемый в быту - вечно движущаяся живая стихия непосредственного творчества, не подчиняюшаяся никакой систематизации и никаким условным рамкам. Характерно, что в любом варианте гопака отчетливо проявляются признаки танцевального соревнования. Стилистический характер исполнения движений напрямую зависит от такого фактора как сиеничность, а в бытовых разновидностях большое значение имеет географическая принадлежность.

Ключевые слова: гопак, танцевальный жанр, сценичность танца, танец, в опере, бытовой вариант гопака.

Relevance of the research topic. A dance as a unique aesthetic phenomenon of human activity occupies a special place among other types of artistic creativity. A variety of phenomena relating to 
the art of dance is beyond any doubts. The expressive possibilities of a dance are endless. A dance is an organic part of many stage forms of musical art. A range of dance genres in the opera is quite wide: from aristocratic, ballroom dances to flashing folk dances. In addition to these types of the dance there is a variety of different genres of classical dance in the opera.

A dance in the opera, in comparison with its genre analogues that exist in performing or everyday dance practice, is specified by special features. Its stage realization is significantly different from the implementation of the same dance, which has centuries-old traditions of everyday life. To analyze their specificity it is necessary, first of all, to consider the main features of musical-dance interaction in each of the existing implementations. The interaction of music and movement in various spheres of musical activity is a relevant musicological problem.

One of the first scientific developments on the theory and history of Ukrainian folk choreography, in which the hopak versions were analyzed in detail, is the fundamental study "Ukrainian Folk Dances" (compiled by A. Gumenyuk, edited by P. Virsky) [4]. The methods and practice of creating contemporary folk-stage choreographic works based on the implementation of traditional folk dance genres are set forth by G. Bogdanov [1]. The article by A. Lyagushchenko researches the influence of choreographic art on the development of theatrical affairs of Ukraine in the historical genesis of the formation of the national theater [7].

According to Y. Pivtorak, the period from the 1950-s until recently, the hopak in Ukraine existed almost exclusively as an art of the stage dance (unlike the diasporas, where over some time it acquired features of social dance and events) related to public holidays [12]. The history of the origin of the hopak as a military-ritual act and its transformation and development in the folk dance works are analyzed by N. Kiptilova [6]. The place and role of female dance in the stage hopak is considered by I. Gutnyk on the example of the performances of famous Ukrainian choreographers [5].

Nevertheless, issues concerning the analysis of the specifics of the implementation of the dance genres in the stage forms of musical art and their analogues in performing and everyday practice, still remain not studied enough. These aspects determined the relevance of this article. 
The purpose of the study is to consider the specifics of the implementation of the hopak genre in the opera and in domestic dance practice.

The statement of the main material. In the art of a dance, a complex composition of motion interacts with the vital, inherent law of a harmonious temporal sequence - the law of a rhythm. The relationship of acoustic and muscular division of time allows us to note a direct connection of the musical rhythm and the rhythm of dance movements. Virtually all dance-related phenomena exist in organic unity with the musical beginning. Indicated properties are inherent in any sample of the dance genre, created both in musical and dramatic works (opera, ballet, etc.), and in their everyday existence. The dance genre is a holistic structure, which, when combined with specific music, determines the spectrum of a wide variety of works.

An important characteristic of various types of dances is their stage performance. The main feature of the stage dance is the possibility of implementation of its meanings on stage by means of the dance art.

Types of dances:

\begin{tabular}{|l|l|l|}
\hline Nearly stage & Pre-stage & Stage \\
\hline ritual & historical-domestic & Classical \\
\hline folk & Ball & National \\
\hline & Salon & Theatre \\
\hline
\end{tabular}

We shall note that any material can be implemented on the stage by dance means (and not only artistic, but also labor processes, domestic conflicts, rituals, etc.). However, a category of stage directly affects the specificity of the implementation of the dance genres. We define the characteristic features of their implementation in the opera.

Each component that contributes to the implementation of a particular dance genre in the opera is distinguished by its specific features compared to its genre analogue, existing in performing or everyday dance practice.

First of all, it is necessary to note the nature of the performance of movements. For a dance performer, the purity and precision of the external pattern in movements, the simplicity and clarity of the form of expression, the accuracy of each stage color, each gesture and intonation, as well as their artistic completeness are important 
in the opera. The technique of performing musical dramaturgy on stage includes a counterpoint of musical rhythm and plastic pattern. The figurative and informative expression of a choreographic action in a specific musical dance form is of significant importance. Thus, the stage dance is a synthetic, multi-component phenomenon.

The formation of the folk-stage dances performed in the opera is connected with the transference and consolidation on the professional stage of the brightest examples of folk dance art and is significantly different from their everyday interpretation.

The most popular genre variety of the Ukrainian popular national dances is the hopak. The name comes from an exclamation "hop" during the "dance performance"; hence the verbs hopaty, hopkaty mean to jump" [8, p. 145]. Traditionally it is believed that the origin of the hopak dates back to the XVI century, to the center of the "Cossack system" - the Zaporozhska Sich. Describing the peculiarities of the life of the Cossacks, M. Hrushevsky writes: "Military music is mentioned - military trumpeters, men who played surma and dovbyshy, beating into boilers and drums" [3, p. 252].

An origin of the hopak in the atmosphere of the formation of the military spirit, suggests that originally the hopak was an exclusively male dance: men showed their strength, dexterity, determination and fighting courage therein. Accordingly, the clothes in which men dance the hopak are similar to the military uniform of the Cossacks. A characteristic feature of the men's suit is wide trousers, the tailoring of which often took up to 10 meters of fabric. The festive costumes were sewn of silk; the shirt with wide sleeves was necessarily tucked into the pants. The Cossacks used different types of belts: wide Turkish (obviously of Oriental origin), belts made of wool or silk, 6-7 meters long, at least 50 centimeters wide $[10$, p. 170]. A wide leather belt - cheres, which the Zaporozhski Cossacks used as a cartridge belt were also especially popular. Despite the fact that there were certain foreign borrowings in the Cossacks' clothes, the establishment of characteristic national peculiarities in Ukrainian costumes is directly related to their images in the hopak dance drama.

The indicated dominance of the male dance in the hopak is still present. However, the gradual development and spread of dance contributed to the appearance of women in it. Therefore, in the stage realization of dance there often was the coupled hopak.

The hopak, performed in the opera, primarily keeps in touch with the folk dance origins, most clearly expresses the mental char- 
acteristics of the Ukrainian ethnos, and is inextricably connected with folk music.

The nature of the performance of movements in the stage variant of the hopak in a fast tempo requires a good physical form of a performer, a high level of technical dance skills.

The stage hopak is structured as a couple-mass dance; it has a certain compositional structure, an ornamental pattern.

It begins with a general "appearance of all couples that are rapidly moving in a circle. Then separate couples, triples, groups that dance separately stand out from the total mass of dancers" [11, p. 84].

A characteristic feature of the hopak is the movement in a circle, which has been a distinctive feature of many dance genre varieties since archaic times. However, quite often the choreographic structure of the dance is based on a figure of an open circle, consisting of dancing couples, and includes solo episodes of a single performer (young man). The main movements are the runner, the flying step, the tap-step, the kovyryalochka, various jumps (in particular - the splits in the jump), the walkway, the squatting dance and circular motions.

A different character of movements can be noted in its everyday performance, distinguished by freedom and improvisational interpretation of time and movements, the sequence of specific dance figures born directly during a dance performance without prior preparation.

The geographical factor influences the stylistic peculiarities of everyday life of the hopak. The hopak is common in many areas of the modern territory of Ukraine. In the central, steppe part of Ukraine, the hopak movements are distinguished by plastic roundness. In Polesie, in the Volyn region, Vinnitsa region, the territory of the Southern Bug River, the movements of everyday dance variations are more variegated, since the dance elements of other peoples are introduced into them. For example, in the dance "Sokal Kozak" the influence of Polish dance is especially noticeable.

The style of performance of stunts in the fighting hopak, created and developed by V. Pilat since 1985, differs significantly from its everyday realization. It is already a Ukrainian martial art, as a means of spiritual and physical training, based on the ancient military traditions of the Zaporozhski Cossacks [9].

The historical predecessor of the hopak is the Cossack dance. The name of the dance, as well as its varieties - Chumak, Haiduk, 
comes from the name of the movements. In the cossack, the extraordinary "courage, daring and mastery of possession of a saber, so characteristic of the Danube Sich" are manifested [2, p. 41].

In everyday life, the hopak is accompanied by instrumental melodies performed by the folk ensemble ("Troisti muzyky"), in a chorus, often by singing of the dance performers themselves.

In the opera samples of this dance, the sound of a symphony orchestra enriches the figurative musical interpretation, emphasizes the close internal connection of stage and musical action. Expressive facial expressions, gesture logic, set design, the use of costumes, which emphasize the originality of the national color, are directly related to the solution of complex tasks assigned to the hopak performer by the drama of the play. Their organic realization contributes to the creation of a multi-component synthetic opera act.

The melodies accompanying the dance emphasize the ideological and emotional content, the heroic coloring of the dance, but sometimes change their character. Their typical stylistic features are a same-plan mode (major or minor), sometimes variable or of the same name, the presence of alteration. The features of the form are the squareness (symmetrical alternation of motives, phrases and sentences in a period), melodies consist mainly of two eight-measure periods; sometimes they have an introduction, code (some consist of 3, 4 or more periods).

The tempo of the dance is moderate; movements are performed widely, with a gradual acceleration, which leads to a climax - the final.

The features of the meter and rhythm are two-beat composition, variational use of the rhythmic formula of anapaest (two eighths and a quarter). This formula is characteristic rhythm-cadence melodies of the hopak.

The various stage forms of the hopak become part of the opera, drama plays, means of disclosing an image in ballet performances (ballet "Marusia Boguslavka" by A. Svechnikov, "Taras Bulba" by V. Solovyov-Sedoy, "Konek-Gorbunok" by Puni, "Gayane" by A. Khachaturian and etc.).

The hopak from the three-act ballet "Taras Bulba" by V. Solovyov-Sedoy based on the novel of the same name by N. Gogol staged by a choreographer R. Zakharov still continues its stage life, being a concert number of outstanding dancers of modernity V. Pisarev, Sh. Yagudin, A. Korsakov and others. 
A stage variant of the hopak, which became an academic variant, was created by the choreographer P. Virsky. One of the most famous Ukrainian professional art dance groups - the National Honored Academic Dance Ensemble of Ukraine - bears his name. And at present, the ensemble traditionally ends its concerts with the performance of the hopak staged by a master founder.

The hopak is a bright, colorful component of the operas of M. Mussorgsky "The Sorochinsky Fair", P. Tchaikovsky "Mazepa", "Tcherevichki", N. Rimsky-Korsakov "May Night" and many other works.

The hopak plays a significant role in the history of Ukrainian opera. In the first Ukrainian professional opera on the national plot of S. Hulak-Artyomovsky "Zaporozhets beyond the Danube", the hopak becomes the genre basis of the suite form. In the second act of the opera, the composer creates a whole gallery of bright Ukrainian dance images. The first dance of the suite (№ 10, Allegretto) is a stage variant of the couple hopak, which is performed by young people (boys and girls). The third dance of the suite (№ 12, Allegretto) is the dance of the Cossacks of the Danube Sich - the Cossack. The next dance suite (№ 13, Moderato) Zaporozhskiy Cossack. № 12 and № 13 are a scenic example of a male-dominated dance in the hopak, in which dance performers are gradually moving from slow, simple steps to quick, virtuoso movements.

In the second act of the opera "The Aeneid" by M. Lysenko, the hopak forms the basis of the central stage of the opera (the feast of the Gods on the top of Olympus). № 15 - the hopak on Olympus (№ 15) is an example of a genre transformation that contributes to the formation of the satirical musical characteristic of Zeus. In this episode, the composer creates a complex, original version of the rondo form, uses the Ukrainian folk melody with its tone-mode characteristic feature, emphasizing the fourth elevated degree. The structure of the number clearly shows signs of a dancing contest; the material is convenient for performing complex movements and stunts.

Conclusions. The heroic historical tradition and natural thrust of the Ukrainian ethnos to the martial arts are decisive factors for the continued popularity of the hopak dance genre, both in everyday life and in various stage forms of musical art. A common feature of different variants of this dance is the basis of the meter and rhythmic structure of the dance - a freely variable foot of the anapest. 
The stylistic nature of the realization of movements depends on factors such as stage design, geographical affiliation of the everyday variant. An accompaniment of the dance in everyday life and in the opera realization is also significantly different.

The stage hopak is a complex, multi-component, artistic and imaginative phenomenon. The hopak, performed in everyday life, is an eternally moving living element of ingenuous creativity, not subject to any systematization and any conditional framework.

The considered specificity of the implementation of the hopak genre in opera and domestic practice shows that the hopak genre retains its importance and relevance, being a genre symbolizing peculiarities of the Ukrainian mentality.

\section{BIBLIOGRAPHY}

1. Богданов Г.Ф. Работа над танцевальной речью. Москва : ВЦХТ, 2006. $160 \mathrm{c}$.

2. Болотов М. Танцы в «Запорожце за Дунаем». М. Болотов, П. Вирский. Запорожец за Дунаем. Постановка Государственного академического театра оперы и балета УССР. Киев / ред. Д.А. Грудина. Харьков : Мистецтво, 1936. С. 41-43.

3. Грушевский М.С. Иллюстрированная история Украины с приложениями и дополнениями / сост. И.И. Брояк, В.Ф. Верстюк. Донецк : БАО, 2004. 768 с.

4. Гуменюк А.І. Українські народні танці. Київ : Наукова думка, 1969. $616 \mathrm{c}$.

5. Гутник I.М. Місце та роль жіночого танцю у сценічному гопаку. Вісник Національної академії керівних кадрів культури і мистеитв. 2018. № 2. С. 211-214.

6. Кіптілова Н. Гопак як один з феноменів українського танцю. Вісник Львівського університету. Серія «Мистецтво». 2014. Вип. 14. C. $75-80$.

7. Лягущенко А.Г. Вплив хореографічного мистецтва на розвиток театральної справи України: історичний аспект. Вісник Національної академії керівних кадрів культури і мистеитв. 2018. № 4. С. 305-310.

8. Музыкальный энциклопедический словарь / гл. ред. Ю.В. Келдыш. Москва : Советская энциклопедия, 1990. 672 с.

9. Пилат В.С. Бойовий гопак. Львів : Логос, 1999. 336 с.

10. Стамеров К.К. Нариси з історії костюмів. Київ : Мистецтво, 1978. $243 \mathrm{c}$.

11. Ткаченко Т.С. Народный танец. Москва : Искусство, 1954. $683 \mathrm{c}$.

12. Pivtorak Y. Ukrainian Hopak: From Dance for Entertainment to Martial Art. Congress on Research in Dance Conference Proceedings, 2016. P. 299-305. 


\section{REFERENCES}

1. Bogdanov, G. F. (2006). Work on the dance speech. Moskva : VTsKhT [in Russian].

2. Bolotov, M. (1936). Dances in "Zaporozhets beyond the Danube". M. Bolotov, P. Virskiy Zaporozhets for the Danube. Staging of the State Academic Opera and Ballet Theater of the Ukrainian SSR Kyiv; ed. D. A. Hrudyna. Kharkov: Mistetstvo [in Russian].

3. Grushevskiy, M. S. (2004). Illustrated history of Ukraine with appendices and additions. Comp. I.I. Broyak, V.F. Verstyuk. Donetsk: BAO [in Russian].

4. Gumenyuk, A. (1969). Ukrainian Folk Dances. Kyiv: Naukova dumka [in Ukrainian].

5. Gutnyk, I. (2018). Place and role of women dance in stage gopak. Bulletin of the National Academy of Cultural and Arts Leaders, 2, 305-310 [in Ukrainian].

6. Kiptilova, N. (2014) Gopak as One of the Phenomena of Ukrainian Dance. Visnyk Lvivskogo Universetetu, 14, 75-80 [in Ukrainian].

7. Lyagushchenko, A. (2018). Influence of choreographic art on the development of the theatrical business of Ukraine: the historical aspect. Bulletin of the National Academy of Cultural and Arts Leaders, 4, 211-214 [in Ukrainian].

8. Musical encyclopedic dictionary (1990) [ch. ed. Yu. V. Keldysh]. Moscow: Sovetskaya entsiklopediya [in Russian].

9. Pylat, V. (1999). Fighting Hopak. Lviv: Lohos [in Ukrainian].

10. Stamerov, K. K. (1978). Essays on the history of costumes. Kyiv: Mystetstvo [in Ukrainian].

11. Tkachenko, T. S. (1954). Folk dance. Moscow: Iskusstvo [in Russian].

12. Pivtorak, Y. (2016). Ukrainian Hopak: From Dance for Entertainment to Martial Art. Congress on Research in Dance Conference Proceedings, 299-305 [in English]. 